This manuscript is a preprint and has been submitted for publication. It has not yet been formally accepted for publication. Subsequent versions of this manuscript may thus have different content. If accepted, the final version of this manuscript will be available via the 'Peer-reviewed Publication DOI' link on the right-hand side of this webpage. Please feel free to contact any of the authors directly with feedback! 


\title{
SALT WELDING DURING CANOPY ADVANCE AND SHORTENING IN THE GREEN CANYON AREA, NORTHERN GULF OF MEXICO
}

\author{
Turki K. Alshammasi*, Sian L. Evans ${ }^{\alpha}$, Christopher A-L. Jackson ${ }^{\# \mu}$ \\ Basins Research Group (BRG), Department of Earth Science \& Engineering, Imperial \\ College, Prince Consort Road, London, SW7 2BP, UK \\ *Present address: Saudi Aramco, Dhahran 31311, Kingdom of Saudi Arabia \\ "Present address: Department of Geosciences, University of Oslo, Sem Scelands vei 1, Oslo, \\ 0316, Norway
}

\#Present address: Department of Earth and Environmental Sciences, The University of Manchester, Williamson Building, Oxford Road, Manchester, M13 9PL, UK

ㄹemail: Christopher.jackson@manchester.ac.uk

\begin{abstract}
Welds form due to the tectonically-induced thinning and/or dissolution of salt, with their composition and completeness thought to at least partly reflect their structural position within the salt-tectonic system. Despite their importance as seals or migration pathways for accumulations of hydrocarbons and $\mathrm{CO}_{2}$, we have relatively few examples of drilled subsurface welds; such examples would allow us to improve our understanding of the processes and products of welding, and to test analytical models of the underlying mechanics. In this study we integrate 3D seismic reflection and borehole data from the Green Canyon Area of the northern Gulf of Mexico, USA to characterize the geophysical and geological expression of a tertiary weld, as well as its broader salt-tectonic context. These data show although it appears complete on seismic reflection data, the weld contains $124 \mathrm{ft}$ (c. $38 \mathrm{~m}$ ) of pure halite. This thickness is consistent with the predictions of analytical models, and with observations from other natural examples of subsurface welds. Our observations also support a model whereby compositional fractionation of salt occurs as the salt-tectonic system evolves; in this model, less mobile and/or denser units are typically stranded within the deeper, autochthonous level,
\end{abstract}


trapped in primary welds, or stranded near the basal root of diapirs, whereas less viscous and/or less dense units form the cores of these diapirs and, potentially, genetically related allochthonous sheets and canopies. We also show that shearing of the weld during downslope translation of the overlying minibasin did not lead to complete welding.

\section{Introduction}

Salt welds form in response to the removal of salt by tectonically-induced thinning and/or dissolution (e.g., Jackson and Cramez, 1989; Rowan, 2004; Wagner \& Jackson, 2011; Jackson et al., 2014; 2018; Jackson \& Hudec, 2017). We can identify three main types of welds depending on the structural level (i.e., autochthonous or allochthonous) at which they occur in a salt-tectonic system; (i) primary; (ii) secondary; and (iii) tertiary (Fig. 1) (Jackson and Cramez, 1989). We can further classify these as complete, incomplete or discontinuous based on the continuity and degree of welding (see Wagner \& Jackson, 2011; see also fig. 1b in Jackson et al., 2014). The type of rock left within an apparent weld (or the incomplete parts of a discontinuous weld) principally reflects the rheological variations between the mobile salt (herein defined as halite) and the less mobile, related lithologies (e.g., anhydrites, carbonates and/or clastics; Kupfer, 1968), and the position of the weld within the overall salt-tectonic system (i.e., primary, secondary, or tertiary; Fig. 1). For example, primary welds may be halitepoor because this high-viscosity, relatively mobile lithology is preferentially expelled (or dissolved) before lower-viscosity, less mobile lithologies. In contrast, tertiary welds formed at structurally shallower levels in the salt-tectonic system may contain only halite, with less mobile components left stranded at depth (Fig. 1).

Regardless of structural level and weld composition, analytical models show that viscous flow alone is rarely sufficient to produce a complete weld (Wagner and Jackson, 2011). In this case, up to $50 \mathrm{~m}$ of salt may remain within the weld, a prediction supported by the very few studies of natural subsurface salt welds (Jackson et al., 2014; 2018). Wagner and Jackson (2011) argue that the remaining salt must be removed by dissolution. However, they also propose that viscous flow with a shear component, perhaps due to the horizontal translation of a suprasalt minibasin onto and along base-salt relief, may promote the complete removal of salt from a weld (Fig. 2). To date, however, relatively simple models linking salt weld composition and structural position, and analytical model-based predictions of weld thickness, have only rarely 
been directly tested by data from natural examples of exposed or subsurface salt welds (Jackson et al., 2014; 2018).

Understanding the composition and thickness of salt welds is critically important to the hydrocarbon industry (Rowan, 2004; Rowan et al., 2012) and those wishing to store $\mathrm{CO}_{2}$ in subsalt reservoirs. Halite typically has very low permeability and can therefore act as a regional or local seal for accumulations of hydrocarbons or $\mathrm{CO}_{2}$. However, welds may act as conduits for gas and fluid migration if they relatively thin and/or composed of non-halite lithologies (e.g., sandstone or carbonate; Jackson et al., 2014). Understanding when a weld forms in relation to the timing of hydrocarbon migration is also important, given welding needs to occur before subsalt source rock expulsion to charge a suprasalt trap (Peel, 2014). In the case of the Gulf of Mexico, the focus of this study, hydrocarbons are found within both subsalt (i.e., primary) and suprasalt (i.e., secondary) minibasins (e.g., K2/K2-North; McBride et al., 1998; and Marco Polo field; Mount et al., 2006), meaning it is also important to understand the role of salt welds in controlling hydrocarbon migration within this particular region. At present, however, there is no clear way to predict if a weld is complete or incomplete due to the lack of well penetrations, limited seismic resolution, and the poor preservation of some evaporite rocktypes (e.g., halite) in the field (e.g., La Popa Basin, Mexico; Rowan et al., 2012; Flinders Range, Australia; Dyson and Rowan, 2004; Hearon et al., 2014; onshore Texas, US; Willis et al., 2001).

In this study, we integrate 3D seismic reflection and borehole data from the Green Canyon area of the northern Gulf of Mexico, USA to characterize the geophysical and geological expression of an apparent tertiary salt weld (Fig. 3). The weld underlies an c. $8.5 \mathrm{~km}$ thick secondary minibasin that subsided into allochthonous salt forming part of the Sigsbee Canopy. Although the weld appears complete on seismic reflection data, our borehole-based analysis shows 124 $\mathrm{ft}(\mathrm{c} .38 \mathrm{~m})$ of pure halite is preserved (i.e., the weld is incomplete, at least at the borehole location, and may be best-classified as discontinuous). This thickness is consistent with the analytical model-based predictions of Wagner \& Jackson (2011), and observations from other natural examples of subsurface salt welds (Jackson et al., 2014; 2018). By studying the structural evolution of the overlying minibasin and flanking salt structures, we also place the weld within its broader salt-tectonic framework, showing that shearing of the weld during downslope translation of the overlying minibasin (see Fig. 1) did not lead to complete welding, at least in the location penetrated by the borehole. 


\section{Geological Setting}

105 The northern Gulf of Mexico initially formed in the Late Triassic-Early Jurassic in response to 106 rifting between the North American and African-South American plates (e.g., Pindell and 107 Dewey, 1982; Kneller and Johnson, 2011; Hudec et al., 2013a). Terrestrial clastic-dominated syn-rift sediments were overlain by a thick, extensive, evaporite-dominated succession known as the Louann Salt, which is approximately dated as Middle to Upper Jurassic (e.g., Hazzard et al., 1947; Humphris, 1978; Salvador, 1987; Kneller and Johnson, 2011; Hudec et al., 2013b).

111 Subsequent gravity-driven flow of these evaporites during the Cenozoic played a primary role 112 in the structural evolution of the Gulf of Mexico and the distribution of overlying sediments.

113 After subsidence of primary minibasins into the autochthonous salt layer, salt flowed out of 114 diapiric feeders and extruded onto and advanced across the seabed, coalescing to form an 115 allochthonous salt layer known as the Sigsbee Canopy (e.g., Diegel et al., 1995; Peel et al., 116 1995; Rowan, 1995; Pilcher et al., 2011). As this canopy advanced basinward during the 117 Oligocene to Miocene, numerous secondary minibasins subsided into and were transported 118 broadly south/south-eastwards on top of the advancing allochthonous body (see Fig. 2a) (e.g., 119 Jackson et al., 2010; Jackson and Hudec, 2017). Previous studies have suggested that the 120 secondary minibasins were carried tens of kilometres basinward before welding (Fig. 2; see also fig. 20 in Jackson et al., 2010; Duffy et al., 2020).

The salt weld of interest in this study is a tertiary weld located below a secondary minibasin that has subsided into the Sigsbee Canopy and welded to the primary minibasin below. This minibasin is situated in the Green Canyon Area of the northern Gulf of Mexico, USA and close to the frontal edge of the advancing canopy (the Sigsbee Escarpment), whose expression can be clearly seen in the present bathymetry (Fig. 3). In a salt tectonic context the studied minibasin and underlying weld lie within the 'amalgamated salt-stock-canopy province' of Pilcher et al. (2011), the upper part of which is characterised by a network of minibasins surrounded by canopy-sourced diapirs and related welds (Fig. 1b).

\section{Data and methods}


136 We use a 3D pre-stack depth migrated (PSDM) seismic reflection volume that covers c. 150 $137 \mathrm{~km}^{2}(12.5 \times 12 \mathrm{~km})$, and which has an inline and crossline spacing of $20 \mathrm{~m}$ (Figs 3 and 4$)$. The 138 volume is cropped at a depth of $23,760 \mathrm{ft}(7,200 \mathrm{~m})$. Seismic data quality is very good within 139 the interval of interest, with the weld and encasing strata being very well-imaged (Fig. 5). We estimate the vertical seismic resolution within the depth interval at which the weld is developed (c. $20,000 \mathrm{ft}$; c. $6.1 \mathrm{~km}$ ) to be c. $62 \mathrm{ft}$ (c. $20 \mathrm{~m}$ ) (resolution is approximated by the assumption that it equals $\lambda / 4$, where $\lambda=80 \mathrm{~m}$ at $20,000 \mathrm{ft}$ ). We display the seismic data using US normal polarity (i.e., a downward increase in acoustic impedance is represented by a negative reflection coefficient, which is a white reflection event in our images; Brown, 2011) (Fig. 5).

We mapped eight key seismic horizons across our 3D seismic reflection dataset; this included top and base salt, and six suprasalt seismic horizons that bound six suprasalt seismic units (SU1-6; Figs 4a-c, 5 and 6). The six suprasalt horizons are defined based on seismicstratigraphic terminations, such as onlaps and erosional truncations (Fig. 5). Thickness maps and stratigraphic relationships are used to determine the tectonic evolution of the minibasin (Figs 4, 5 and 7). The ages of the horizons, which span the Miocene to Recent, are directly constrained (i.e., top SU3 and SU6) or estimated (i.e., top SU1-2 and SU4-5) from biostratigraphic data obtained from a borehole penetrating the central, thickest part of the minibasin and its underlying weld (Figs 4b-d, 5e and 6). An age-constrained seismicstratigraphic framework is important because it enables us to determine the timing and duration of the major salt-tectonic events, including the likely timing of welding.

\section{Borehole data}

160 We use data from a borehole that was drilled in a water depth of c. 4,200 ft (1,300 m) to a total 161 depth of 30,803 ft (9,389 m). Borehole-related datasets include well-logs, and mudlogging, 162 biostratigraphic, and operational reports. Well-logs cover the interval 4,235-21,422 ft (1,290$1636,529 \mathrm{~m}$ ), which includes the studied weld (Fig. 6). Well-logs include gamma ray (gAPI), sonic $164(\mu \mathrm{s} / \mathrm{ft})$, density $\left(\mathrm{g} / \mathrm{cm}^{3}\right)$, neutron $\left(\mathrm{ft}^{3} / \mathrm{ft}^{3}\right)$, caliper (in) and deep resistivity (ohm-m) (Fig. 4). We used data from these well-logs to determine weld lithology and thickness, which helped understand its sealing potential. These logs also helped constrain the lithology of material 
above and below the weld, which was critical when considering its seismic expression at and lateral to the borehole location. Biostratigraphic samples span 10,920-22,300 $\mathrm{ft}(3,328-6,797$ $\mathrm{m}$ ) and were examined by the borehole operator and partners at $30 \mathrm{ft}(9.1 \mathrm{~m})$ increments. Because these data are confidential, we report here only the key geological age boundaries (Fig. 6).

\section{Salt-tectonic structure}

Allochthonous salt overlies a reflective, clastic-dominated succession, the uppermost part of which is Tortonian-to-earliest Messinian (i.e., Late Miocene; Figs 5 and 6). The base of the allochthonous salt is rugose, consisting of a prominent, NW-trending, steeply SW-dipping ramp $\left(\right.$ c. $\left.30^{\circ}\right)$ that is at least $5000 \mathrm{ft} \mathrm{km}(1,524 \mathrm{~m})$ long and defines relief of at least $2000 \mathrm{ft}$ (609 m) (Figs 4a, 4d, 5a and 5d). North of this ramp, base-salt dips gently (c. $3^{\circ}$ ) to the WNW, although low-relief rugosity of a few hundred metres is also locally observed in this area (Figs $4 \mathrm{a}$, and 5a-b). Where the base-salt reflection lies beneath the seismic reflection volume, such as in the west of the study area, we infer the presence of a diapiric feeder that provided salt to the Sigsbee Canopy (Pilcher et al., 2011; Jackson et al., 2018) (Figs 4a, 4d and 5e). As we will discuss below, base-salt relief, in particular the NW-trending ramp and the local structural high it delineates, are important controls on the structural development of the suprasalt minibasin.

Allochthonous salt

Diapiric allochthonous salt, which is up to $21724 \mathrm{ft}(6,621 \mathrm{~m})$ thick, almost fully encircles the studied minibasin (Figs 4b-d and 5). A discontinuous weld is present beneath the minibasin; this weld comprises areas of (apparently) complete welding and small, elongate, wall-like pockets of salt that are up to $3750 \mathrm{ft}(1,143 \mathrm{~m})$ thick and $2000 \mathrm{ft}$ wide (Figs $4 \mathrm{~b}$ and 5). Some of these pockets occur in the footwall of salt-detached, intra-minibasin thrusts (Figs 5a and 5b) or at the base of sub-vertical welds (Fig. 5d) (see below). 
200 The suprasalt minibasin contains clastics that are Serravallian (Middle Miocene) to Holocene 201 (Fig. 6). It is important to note that the strata directly above the weld are older (Serravallian) 202 than the strata directly underlying it (Messinian) (c. $20300 \mathrm{ft}$; Fig. 6); we discuss the 203 significance of this observation below. The geometry of the top salt surface (Fig. 4), and 204 thickness changes in its lowermost part (Fig. 4c), indicate the studied minibasin is, at least in 205 its lower part, composed of at least seven smaller, broadly bowl-shaped sub-basins (labelled 206 A-G; Fig. 4d; see also Fig. 5). These sub-basins are separated by salt-detached thrusts that have pockets of salt preserved in their footwall (see above; Fig. 5a and b) or sub-vertical welds (Figs $3 \mathrm{~b}, 3 \mathrm{~d}$ and $5 \mathrm{~d}$ ). These thrusts show highly variable strikes (i.e., N-S to ENE-WSW) and dips (i.e. W to SSE), but we note that they restricted to the northern side of the base-salt ramp and its related structural high (Fig. 5d). All of the salt-detached thrusts are flanked by hangingwall anticlines and footwall synclines, and are overlain by unbreached monoclines, which we interpret as fault-propagation folds (Fig. 5a-c). Strata within the lower sub-basins and within the overlying, larger, singular minibasin, thin towards and onlap onto flanking diapirs (most

214 clearly seen in Fig. 5d-e; see also 5a-b). We provide a more detailed description of the minibasins seismic-stratigraphic patterns below.

\section{Supra-salt minibasin seismic stratigraphy and evolution}

Vertical changes in seismic-stratigraphic patterns and stratal thickness (Figs 5 and 6) suggest the studied minibasin initially comprised at least seven sub-basins and underwent six main stages of structural development. We describe and interpret these sub-basins and related stages below (see Fig. 10), using the age-constrained seismic-stratigraphic framework (Fig. 6) to constrain their timing and duration.

Stage 1 (Serravallian-Messinian)

The thickness map of SU1 shows at least seven distinct sub-basins (A-F and H; Fig. 7a). The sub-basins contain broadly bowl- to locally wedge-shaped seismic packages (Fig. 5). Strata within these packages onlap the large, flanking diapirs and the pockets of salt locally preserved beneath the minibasin (Fig. 5). 
232 Based on these observations we interpret that the minibasin was initially comprised of seven 233 smaller minibasins that independently subsided symmetrically and sub-vertically (where 234 containing bowl-shaped packages), or slightly asymmetrically (where containing wedge235 shaped packages) into the allochthonous salt canopy during a phase of passive diapirism (Fig. 236 10A and B) (e.g., Rowan \& Weimer, 1999; Jackson et al., 2019). Although hard to prove at 237 this particular locality, we suggest that these minibasins were located updip (i.e., north) of their 238 present location and were translating basinward (i.e., broadly southward) above the advancing 239 salt canopy, consistent with other minibasins documented in this area (Fig. 10A and B) (see 240 Jackson et al., 2010; see also Duffy et al., 2020 and Fernandez et al., 2020).

Stage 2 (Messinian)

In contrast to SU1, which defined seven sub-basins, depocentres within SU2 define only four sub-basins; a relatively large, bowl-shaped depocentre centred on the borehole (an amalgamation of sub-basins A, D and E) and two smaller sub-basins located to the north (subbasin B, and sub-basins C and F, which are now linked; Fig. 7b). Strata within these sub-basins still onlap the large diapirs flanking the host minibasins although they do not onlap intraminibasin diapirs, which were buried by strata within the upper part of SU1 (Fig. 5). Instead, SU2 thins across, and the larger minibasin is segmented by, fault-related folds above the upper tips of intra-minibasin thrusts forming the boundary between, for example, sub-basins B and A (Fig. 5a), B and C (Fig. 5b), C and D (Fig. 5b), and A and E (Fig. 5a).

These seismic-stratigraphic relationships indicate that the intra-minibasin thrusts became active, and thus that the causal shortening initiated, in the Messinian (see also Figs $7 \mathrm{~b}$ and 10C). We suggest that the low-relief diapirs that previously separated sub-basins defined by SU1 were squeezed and the sub-basins collided to form steeply dipping thrust welds, with small pockets of the salt beneath these welds representing remnant diapir pedestals (Figs $5 \mathrm{~d}$-e and 10C). The origin of the intra-minibasin shortening is not clear, although we speculate this could reflect the onset of welding of the suprasalt minibasin as it translated onto, and was buttressed against, the broadly, gently NW-dipping base-salt ramp (Fig. 10C) (e.g., Duffy et al., 2020). 
265 SU3 lies conformably above SU2 but is capped by a major angular unconformity that truncates 266 underlying reflections (Fig. 5). Although influenced by the capping erosional surface (Fig. 5), 267 thickness patterns within SU3 clearly differ to those observed in SU1 and SU2. First, only two 268 main depocentres are defined; (i) a broadly NE-trending depocentre north of the borehole 269 spanning sub-basins C, F, and the northern part of A; and (ii) a sub-circular depocentre 270 spanning sub-basins B and G (Figs 5 and 7c). Second, these thickness patterns are less 271 obviously controlled by intra-minibasin thrusts or diapirs, although stratigraphic thinning above and onlap onto thrust-related folds are locally observed (Fig. 5a-c).

These observations suggest that shortening-related thrusting continued into the Piacenzian, implying welding-related deformation was ongoing (Fig. 10C). Welding-related shortening and tilting, combined with an influx of sediment across the evolving canopy, may have led to the development of the erosional unconformity capping SU3 (not shown in Fig. 10).

Stage 4 (Gelasian-Pleistocene)

SU4 displays overall thickening towards the NW. However, in the northern part of the study area we observe two sub-circular depocentres (Fig. 7D), related to the filling of erosional relief developed along the top Pliocene erosional unconformity (see Fig. 5B). Most critically, however, SU4 shows no thickness changes with respect to the thrust-related folds, indicting the minibasin was less segmented, and was subsiding as a single, large depocentre by the Gelasian (Figs 5, 7D and 10D). This also suggests that welding-induced, intra-minibasin shortening has ceased by the Gelasian. SU4 also differs to SU2 and SU3 in that it is dominated by broadly layer- to weakly wedge-shaped seismic packages that overstep and cap the large, minibasin-flanking diapirs (Fig. 5).

The dominance of areal extensive, layer-shaped, diapir-capping packages indicates passive diapirism may also have ceased at this time, possibly due to weld-induced termination of salt supply to the flanking diapirs (see Rowan and Weimer, 1989; Jackson et al., 2019). However, the shift in depocentre toward the NW, combined with the weakly wedge-shaped seismic packages observed in similarly trending seismic profiles (Fig. 5a and 5b), suggests that the minibasin was tilting broadly north-westwards at this time (Fig. 10D). Given we infer that the minibasin had welded by this time, we suggest minibasin tilting was triggered by differential active rise of flanking diapirs during ongoing shortening (Fig. 10D) (Fernandez et al. 2020). 
SU5 comprises broadly tabular packages of sub-parallel reflections that locally thin towards flanking diapirs at the minibasin margins, but which invariably cap these structures (Figs 5 and 7e). At this shallow structural level, we observe salt-detached thrusts at the minibasin margins (Fig. 5c-d). These relatively low-displacement $(<50 \mathrm{~m})$ thrusts are best-developed in the NE of the minibasin, where they dip NE and strike NW-SE.

The dominance of layer-shaped seismic packages suggests minibasin subsidence had ceased and aggradation above the now-welded depocentres continued (Rowan and Weimer, 1998; Jackson et al., 2019). However, thinning of strata within SU5 towards flanking diapirs suggests these structures continued to actively rise, possibly in response to ongoing shortening within the canopy. This shortening may have also been accommodated by the development of shallow-level thrusts (Figs 5a, 5b and 10E).

\section{Stage 6 (Late Pleistocene-Holocene?)}

SU6 defines a NW-trending depocentre characterised by broadly layer-shaped seismic packages that cap and show only moderate thickness changes within respect to minibasinflanking diapirs (Figs 5 and 7f). Based on this seismic-stratigraphic architecture, which is crudely like that observed in SU5, we suggest the latest Pleistocene to Holocene was characterised by only minor salt tectonics (e.g., minibasin subsidence and/or diapir rise), and dominated by deep-water sediment aggradation (Fig. 10E).

\section{Salt weld thickness and composition}

The salt-bearing interval penetrated by the borehole (i.e., the weld) is characterised by anomalously low gamma ray values (c. 24 gAPI), high density (2.4-2.95 g/cm 3 ), low neutron porosity (-0.5-0.2 pu.), high resistivity (c. $\left.10^{3}\right)$, low sonic slowness (c. $68 \mathrm{~s} / \mathrm{ft}$ ) (i.e., it has a high p-wave velocity) (Figs 8 and 9). We note there is some scatter in these values, particularly

330 in terms of density and sonic slowness (i.e., velocity), an observation we discuss further below.

331 Based on these criteria, we confidently picked, stratigraphically rather than seismically, top salt at $20255 \mathrm{ft}(6174 \mathrm{~m})$ and base-salt at $20379 \mathrm{ft}(6212 \mathrm{~m})$, interpreting that the (apparent) 
weld is $124 \mathrm{ft}(38 \mathrm{~m}$ ) thick and dominated by halite (Fig. 9) (Rider and Kennedy, 2011; Jackson

334 et al., 2014, 2018). Mudlogging reports are consistent with our well-log-based interpretation, 335 describing only halite from this approximate depth interval. We also, however, note that the 336 halite is: (i) denser (by c. 0.4-1 g/ $\mathrm{cm}^{3}$ ) than ideal values (Rider and Kennedy, 2011) and values 337 documented from elsewhere in the northern Gulf of Mexico for this rock type (Jackson et al., 338 2018); and (ii) acoustically faster (by sonic slowness values of c. 20-40 us/ft) than values 339 documented from elsewhere in the northern Gulf of Mexico for this rock type (Jackson et al., 340 2018). We explore the potential reasons for this further in the Discussion.

\section{INTERPRETATION AND DISCUSSION}

\section{Age and salt-tectonic context of the salt weld}

Previous regional studies suggest canopy emplacement in this area of the northern Gulf of Mexico occurred during the Middle-Late Miocene in response to regional shortening and the related extrusion of salt from diapiric feeders (Peel et al. 1995). Using 3D seismic reflection and borehole data, Jackson et al. (2018) interpret that canopy emplacement in the Atwater Valley area, c. $100 \mathrm{~km}$ to the ENE of our study area, was in fact considerably later, sometime in the Early Pleistocene. Our observation that the weld (and laterally equivalent salt structures forming the canopy) studied here is underlain and overlain by late Miocene (Messinian) and middle Miocene (Serravallian) strata, respectively, suggests canopy emplacement in the middle to late Miocene, consistent with the age originally proposed by Peel et al. (1995). Given that we use seismic reflection data of a broadly similar vintage and, we infer, quality to that of Jackson et al. (2018), we propose that the difference in local canopy emplacement reflects regional diachroneity in the timing of emplacement, rather than dataset quality (i.e., borehole data are of sufficient resolution to constrain the age of sub- and suprasalt rocks and, thus, the timing of canopy emplacement; see Jackson et al. 2018). More specifically, given that the canopy was fed by squeezed diapirs (i.e., feeders) during regional shortening, this diachroneity might reflect systematic changes in the timing of shortening and related squeezing. For example, feeders in the Atwater Valley area of Jackson et al. (2018) may have been shortened and expelled salt later than elsewhere, meaning the canopy advanced into this area only after a period of latest Miocene and Pliocene sediment aggradation. An alternative interpretation is that shortening was regionally synchronous, but that locally higher sediment accumulation 
rates in the Atwater Valley area meant that salt expulsion from feeders and break-out into a canopy was delayed by aggrading sediment in flanking minibasins.

The age inversion observed in the borehole (i.e., Serravallian strata overlying younger Messinian across an incomplete salt weld) likely reflects the overall salt-tectonic setting and evolution of the study area, in particular the downslope translation of the minibasin within an evolving canopy and subsequent welding. We interpret that deep-water sedimentation within the developing minibasin commenced in the Serravallian when the structure was located some unconstrained distance upslope to the north. Ahead of the advancing canopy and secondary minibasin, younger sediment (i.e., Tortonian and the earliest Messinian) continued aggrading within primary minibasins. As a result, an age inversion occurred when the secondary minibasin translated onto, and eventually welded to, the underlying primary minibasin (e.g., Duffy et al., 2020; Fernandez et al., 2020).

Canopy dynamics and related welding also controlled minibasin structural style by driving early thrusting and folding (Fig. 10C). Contractional structures such as these are common on salt-detached slopes, forming when minibasins collide due to; (i) an unwelded, mobile minibasin colliding with a welded, immobile minibasin (i.e., it becomes "obstructed"; sensu Duffy et al., 2020); or (ii) two welded, yet still mobile minibasins colliding due to ongoing shortening (Jackson et al., 2008; Duffy et al., 2021). In the former case, the contractional structures most commonly develop during the latter stages of minibasin development, once minibasins become thick enough to touch down on the base-salt surface, thus welding and forming an obstruction. This is typically associated with the squeezing and eventual secondary welding of intervening diapirs, which readily explains the formation of the relatively young thrusts and related secondary welds at relatively shallow levels on the NE margin of the studied minibasin (Fig. 5C, D). However, the relatively old contractional structures observed at the base of the minibasin show that here the collision of sub-basins occurred during the very early stages of minibasin development, when the depocentre was relatively thin (i.e., c. 30\% of its eventual total thickness; Fig. 10C) and presumably surrounded by thick salt (Figs 4C and 5). In this case, we might expect that shortening would have been absorbed by the relatively weak salt rather than the relatively strong minibasin (Rowan and

395 Vendeville, 2006; Duffy et al., 2021). We tentatively suggest that early shortening was induced by obstruction of the southwards translating sub-basins by the NE-dipping base-salt ramp. As the most seaward sub-basin migrated southwards it became grounded against the ramp and welded to the shallowing base-salt surface (i.e., sub-basin E; Fig. 4D). Unable to translate 
further, it was then collided into by still-translating, updip sub-basins (i.e., sub-basins A and D; Fig. 4D).

\section{Geological, geophysical, and petrophysical expression of welds and implications for the} process of welding

Although they are readily imaged in seismic reflection data from a range of salt-tectonic settings, there are relatively few published examples of salt welds penetrated by boreholes. Such data are required to determine the completeness, composition, and petrophysical expression of the weld and encasing wall rocks. Jackson et al. (2014) show that a primary weld in the Santos Basin, offshore Brazil is incomplete (sensu Wagner, 2010; Wagner and Jackson, 2011), containing $22 \mathrm{~m}$ of carbonate, anhydrite, sandstone, and marl, with halite absent. A tertiary weld in the Atwater Valley area of the northern Gulf of Mexico is also incomplete; however, rather than being halite-poor, this c. $24 \mathrm{~m}$ thick weld is halite-dominated and contains a 4 m-thick mudstone inclusion (Jackson et al., 2018). Although data remain sparse, current observations of salt composition and thickness are consistent with a model whereby compositional fractionation of salt occurs as the salt-tectonic system evolves, i.e. more viscous, less mobile and/or denser units are typically stranded within the deeper, autochthonous level, trapped in primary welds, or stranded near the basal root of diapirs, whereas less viscous and/or less dense units form the cores of these diapirs and, potentially, genetically related allochthonous sheets and canopies (Fig. 1) (cf. 'differential purification by movement': Kupfer 1968; see also Wagner \& Jackson 2011; Jackson et al. 2014; 2018). Current data are also consistent with the predictions of analytical and numerical models presented by Wagner \& Jackson (2011), which suggest natural salt welds formed by viscous flow alone may contain anywhere from $\ll 1 \mathrm{~m}$ to up to c. $50 \mathrm{~m}$ of remnant salt. Viscous flow may therefore be a good analytical approximation of the physical processes occurring during salt thinning and welding; viscous flow alone is unlikely, however, to result in complete evacuation of salt.

Our borehole data from the northern Gulf of Mexico allow us to further test and refine these related models for salt welding during the development of multi-level salt-tectonic systems. Our data indicate that the seismically imaged tertiary weld is incomplete (i.e., it is an "apparent weld"; sensu Jackson et al., 2014), being defined by c. $124 \mathrm{ft}$ (38 m) of remnant evaporitic rocks (i.e., halite). This thickness is slightly more than previously documented in the Santos Basin (Jackson et al., 2014) and elsewhere in the northern Gulf of Mexico (Jackson et 
433 flow (Wagner and Jackson, 2011). The halite has a very clear expression in well-log data, being

434 characterised by relatively very low radioactivity (as expressed in gamma-ray log data), and

435 high density, velocity (i.e., low acoustic slowness), and resistivity. However, as noted above;

436 (i) our cross-plot of halite density and velocity displays some scatter (Fig. 9); and (ii) the halite

437 is denser than ideal values for this rock type (Rider and Kennedy, 2011) and values documented

438 from natural halite penetrated elsewhere in the northern Gulf of Mexico for this rock type

439 (Jackson et al., 2018), and acoustically faster than values documented from elsewhere in the

440 northern Gulf of Mexico (Jackson et al., 2018). The former observation might suggest the halite

441 could be slightly impure due to the presence of disseminated grains or thin laminae of denser

442 and acoustically faster (e.g., carbonate), or less dense and acoustically slower (e.g., siliciclastic)

443 material; we infer that this effect, if present, is only very minor, given that the halite retains

444 very different petrophysical properties to that of encasing clastic rocks (Fig. 9). Determining

445 why the halite is denser and acoustically faster is more challenging, but it might reflect the fact

446 that different logging tools and drilling approaches (e.g., drilling fluids) were used to acquire

447 the data in the different boreholes.

$448 \quad$ Notwithstanding its slightly unusual petrophysical expression, the occurrence of only

449 halite within the tertiary weld is consistent with a model of rheologically-controlled

450 compositional fractionation, i.e., the less mobile units (e.g., clastic, carbonate, or anhydrite

451 rocks) remain at the deeper, autochthonous level, trapped in primary welds, whereas more

452 mobile units (e.g., halite, potash salts) flow into diapiric salt structures and canopies, thus

453 dominating salt composition at the allochthonous level (Fig. 1). As such, when allochthonous

454 salt welds, we suggest these secondary and tertiary welds will be relatively enriched in halite

455 and possibly potash salts, as opposed to halite-poor primary welds. This is the case in the

456 example presented here, although we note that the compositional variability encountered in salt

457 welds will also likely reflect several factors such as compositional variations in the

458 autochthonous salt or preferential dissolution of more soluble salts (e.g., halite and bittern 459 salts).

461 Why is there salt left in the weld?

463 Two main processes control the evacuation and removal of salt in a weld; dissolution and solid464 state flow (Jackson and Hudec, 2017). We do not think dissolution played a role in salt thinning 465 and/or was able to fully remove the remaining salt from the weld due to the weld being buried $466>1 \mathrm{~km}$ (around 3,300 ft); at such depths sluggish water flow are anticipated, limiting 
dissolution, even if a large amount of NaCl-undersaturated water is present (Jackson and 468 Hudec, 2017). Welding by solid-state flow is more plausible, although Wagner and Jackson 469 (2011) use analytical solutions to show that viscous flow alone cannot fully remove salt from 470 a weld due to boundary drag along the perfectly flat and parallel, upper and lower contacts. 471 Because of this process, they suggest that 1-50 m (3-165 ft) of residual salt will remain in a weld, a range consistent with the thickness of salt observed here $(38 \mathrm{~m})$, and in welds in the Santos Basin, Brazil (22 m; Jackson et al., 2014) and elsewhere in the northern Gulf of Mexico (24 m; Jackson et al., 2018).

Borehole and field data demonstrate complete welding is at least locally possible along incomplete welds (Rowan et al., 2012; Jackson and Hudec, 2017). Based on analytical models, Wagner and Jackson (2011) hypothesize that shear-thinning could lead to the complete removal of salt from a weld. Our interpreted structural evolution based on seismic-stratigraphic analysis and borehole data suggests that the basal weld of the studied minibasin has been sheared. More specifically, the presence of squeezed diapirs, and thrusts and related secondary welds in the lower parts of the minibasin suggests horizontal shortening, which we infer occurred after the minibasin had welded onto an upslope-dipping, base-salt ramp. Despite this, the weld is incomplete, suggesting that more shearing is required to fully remove all the salt from a weld.

\section{Implications for hydrocarbon exploration and the storage of $\mathrm{CO}_{2}$}

Salt has relatively low permeability and can therefore form a high-quality seal to underlying or laterally adjacent accumulations of hydrocarbons or $\mathrm{CO}_{2}$ (e.g., Warren, 2016). The precise sealing properties of salt are at least partly dictated by its thickness and composition, i.e., all other things being equal, a relatively thin $(<10 \mathrm{~m})$, incomplete, halite-dominated tertiary weld may be a better seal than a substantially thicker primary weld dominated by carbonates and clastics. The differential purification by movement-model outlined above might, with further testing by borehole data, be refined and may ultimately be predictive.

\section{Conclusions}

We used 3D seismic reflection and borehole data from the Green Canyon Area of the northern Gulf of Mexico, USA to characterize the geophysical and geological expression, and the regional salt-tectonic structural context of a tertiary salt weld. The weld is developed at the base of a secondary minibasin that likely translated seaward in allochthonous salt of the Sigsbee 
501 Canopy, before colliding with and welding to a base-salt ramp. Welding and the related 502 collision of otherwise mobile minibasins led to at least two phases of shortening, both of which 503 were associated with the development of salt-detached thrusts and folds, and secondary welds.

504 The seaward translation and eventual welding of the minibasin also led to an across-weld 505 stratigraphic repetition, with Serravallian strata overlying younger Messinian strata. Our 506 petrophysical analysis of borehole data showed that although it appears complete on seismic 507 reflection data, and although it may have undergone some shortening-related shearing, the 508 basal weld is in fact incomplete, containing $124 \mathrm{ft}(\mathrm{c} .38 \mathrm{~m})$ of pure halite. This thickness is 509 consistent with observations from other natural examples of subsurface welds, and with the 510 predictions of analytical models of welding by viscous flow. Our observations support a model 511 in which compositional fractionation of salt occurs as the salt-tectonic system evolves; in this 512 model, less mobile and/or denser units are typically stranded within the deeper, autochthonous 513 level, trapped in primary welds, or stranded near the basal root of diapirs, whereas less viscous 514 and/or less dense units form the cores of these diapirs and, potentially, genetically related 515 allochthonous sheets and canopies. More studies of drilled subsurface welds are required to 516 assess the processes (i.e., mechanics) and products of salt welding, and the role they play in 517 the trapping of hydrocarbons and the storage of $\mathrm{CO}_{2}$.

\section{Acknowledgements}

We thank BHP for permission to use and show their proprietary seismic and borehole data, and Schlumberger for providing Petrel software to Imperial College via an Academic License Agreement. We thank Ryan Lewis, Neil Evans, Erik Peterson, Kanetra Moses, Rody Alzona, and Tom Hider for facilitating data access and transfer, and for general support of our research. Oliver Duffy, Naiara Fernandez, and Mike Hudec are also thanked for very helpful discussions during this study.

\section{References}

530 Brown, A.R. 2011. Interpretation of three-dimensional seismic data, $7^{\text {th }}$ edition. AAPG 531 Memoir, 42/SEG Investigations in Geophysics, 9, pp315.

533 Diegel, F.A., Karlo, J.F., Schuster, D.C., Shoup, R.C. and Tauvers, P.R. 1995. Cenozoic structural evolution and tectono-stratigraphic framework of the northern Gulf Coast continental 
margin. In: Jackson, M.P.A., Roberts, D.G. \& Snelson, S. (eds) Salt Tectonics: A Global

Duffy, O.B., Fernandez, N., Peel, F.J., Hudec, M.R., Dooley, T.P. and Jackson, C.A.-L. 2020. Obstructed minibasins on a salt-detached slope: An example from above the Sigsbee canopy, northern Gulf of Mexico. Basin Research, 32, 505-524.

Duffy, O.B., Dooley, T.P., Hudec, M.R., Fernandez, N., Jackson, C.A.-L. and Soto, J.I. (in press). Principles of Shortening in Salt Basins Containing Isolated Minibasins. Basin Research.

Dyson, I.A. and Rowan, M.G. 2004. Geology of a welded diapir and its flanking minibasins in the Flinders Ranges of South Australia. Proceedings of GCSSEPM Foundation $24^{\text {th }}$ Annual Bob F. Perkins Research Conference, 390-403.

Fernandez, N., Duffy, O.B., Peel, F.J. and Hudec, M.R. 2021. Influence of minibasin obstruction on canopy dynamics in the northern Gulf of Mexico. Basin Research, 33, 427-446.

Hazzard, R.T., Spooner, W.C. and Blanpied, B.W. 1947. Notes on the stratigraphy of the formations which underlie the Smackover Limestone in south Arkansas, northeast Texas, and north Louisiana. In: Shreveport Geological Society Reference Report on Certain Oil and Gas Fields of North Louisiana, South Arkansas, Mississippi and Alabama, Volume II. Shreveport Geological Society, Shreveport, IL, USA, 483-503.

Hearon, T.E., IV, Rowan, M.G., Lawton, T.F., Hannah, P.T. and Giles, K.A. 2014. Geology and tectonics of Neoproterozoic salt diapirs and salt sheets in the eastern Willouran Ranges, South Australia. Basin Research, 27, 183-207.

Hudec, M.R., Jackson, M.P.A. and Peel, F.J. 2013a. Influence of deep Louann structure on the evolution of the northern Gulf of Mexico. AAPG Bulletin, 97, 1711-1735. 
568 Humphris, C.C., Jr. 1978. Salt movement on continental slope, northern Gulf of Mexico. In:

569 Bouma, A.H., Moore, G.T. \& Coleman, J.M. (eds) Framework, Facies, and Oil-Trapping

570 Characteristics of the Upper Continental Margin. AAPG Studies in Geology, 7, 69-86.

572 Jackson, C.A.-L., Rodriguez, C.R., Rotevatn, A. and Bell, R.E. 2014. Geological and 573 geophysical expression of a primary salt weld: An example from the Santos Basin, Brazil. Interpretation, 2, SM77-SM89.

575

Jackson, C.A.-L., Zhang, Y., Herron, D.A. and Fitch, P. 2018. Subsurface expression of a salt weld, Gulf of Mexico. Petroleum Geoscience, 25, 102-111.

Jackson, C.A.-L., Duffy, O.B., Fernandez, N., Dooley, T.P., Hudec, M.R., Jackson, M.P.A. and Burg, G. 2020. The stratigraphic record of minibasin subsidence, Precaspian Basin, Kazakhstan. Basin Research, 32, 739-763.

582

Jackson, M.P.A. and Cramez, C. 1989. Seismic recognition of salt welds in salt tectonics regimes: Gulf of Mexico salt tectonics, associated processes and exploration potential: Gulf Coast Section-SEPM Foundation 10 ${ }^{\text {th }}$ Annual Research Conference, 66-71.

Jackson, M.P.A, Hudec, M.R., Jennette, D.C. and Kilby, R.E. 2008. Evolution of the Bulletin, 92, 487-511.

Jackson, M.P.A, Hudec, M.R. and Dooley, T.P. 2010. Some emerging concepts in salt tectonics in the deepwater Gulf of Mexico: intrusive plumes, canopy-margin thrusts, minibasin triggers and allochthonous fragments. In: Vining, B.A. and Pickering, S.C. (eds) Petroleum Geology:

594 From Mature Basins to New Frontiers-Proceedings of the 7th Petroleum Geology Conference, 899-912. 
600 Kneller, E.A. and Johnson, C.A. 2011. Plate kinematics of the Gulf of Mexico based on 601 integrated observations from the Central and South Atlantic. Gulf Coast Association of 602 Geological Societies Transactions, 61, 283-300.

604 McBride, B.C., Weimer, P. and Rowan, M.G. 1998. The effect of allochthonous salt on the 605 petroleum systems of northern Green Canyon and Ewing Bank (offshore Louisiana), northern 606 Gulf of Mexico. AAPG Bulletin, 82, 1083-1112.

Mount, V. S., Rodriguez, A., Chaouche, A., Crews, S.G., Gamwell, P. and Montoya, P. 2006.

609 Petroleum system observations and interpretation in the vicinity of the K2/K2-North, Genghis 610 Khan, and Marco Polo fields, Green Canyon, Gulf of Mexico. Gulf Coast Association of 611 Geological Societies Transactions, 56, 613-625.

Peel, F.J. 2014. How do salt withdrawal minibasins form? Insights from forward modelling, and implications for hydrocarbon migration. Tectonophysics, 630, 222-235.

616 Peel, F.J., Travis, C.J. and Hossack, J.R. 1995. Genetic structural provinces and salt tectonics 617 of the Cenozoic offshore U.S. Gulf of Mexico: A preliminary analysis. In: Jackson, M.P.A., 618 Roberts, D.G. \& Snelson, S. (eds) Salt Tectonics: A Global Perspective. AAPG Memoir, 65, $619 \quad 153-175$.

Pindell, J. and Dewey, J.F. 1982. Permo-Triassic reconstruction of western Pangea and the evolution of the Gulf of Mexico/Caribbean region. Tectonics, 1, 179-211.

Pilcher, R.S., Kilsdonk, B. and Trude, J. 2011. Primary basins and their boundaries in the deepwater northern Gulf of Mexico: Origin, trap types, and petroleum system implications. AAPG Bulletin, 95, 219-240.

628 Rider, M. and Kennedy, M. 2011. The geological interpretation of well logs, $3^{\text {rd }}$ edition. Rider629 French Consulting Limited.

631 Rowan, M.G. 1995. Structural styles and evolution of allochthonous salt, central Louisiana 632 outer shelf and upper slope. In: Jackson, M.P.A., Roberts, D.G. \& Snelson, S. (eds) Salt 633 Tectonics: A Global Perspective. AAPG Memoir, 65, 199-228. 
635 Rowan, M.G. 2004. Do salt welds seal? In: Post, P.J., Olson, D.L., Lyons, K.T., Palmes, S.L.

636 Harrison, P.F. \& Rosen, N.C. (eds) Salt-Sediment Interactions and Hydrocarbon Prospectivity:

637 Concepts, Applications, and Case Studies for the $21^{\text {st }}$ Century. Proceedings of the GCSSEPM

638 Foundation $24^{\text {th }}$ Annual Bob F. Perkins Research Conference. GCSSEPM Foundation, Austin, 639 TX, USA, 390-403.

641 Rowan, M.G. and Weimer, P., 1998. Salt-sediment interaction, northern Green Canyon and 642 Ewing bank (offshore Louisiana), northern Gulf of Mexico. AAPG Bulletin, 82, 1055-1082.

644 Rowan, M.G., Lawton, T.F. and Giles, K.A. 2012. Anatomy of an exposed vertical salt weld 645 and flanking strata La Popa Basin, Mexico. In: Alsop, G.I., Archer, S.G., Hartley, A.J., Grant, 646 N.T. \& Hodgkinson, R. (eds) Salt Tectonics, Sediments and Prospectivity. Geological Society, 647 London, Special Publications, 363, 33-57.

Rowan, M.G. and Vendeville, B.C. 2006. Foldbelts with early salt withdrawal and diapirism: Physical model and examples from the northern Gulf of Mexico and the Flinders Ranges, Australia. Marine and Petroleum Geology, 23, 871-891.

Wagner, B.H., III. 2010. An analysis of salt welding. PhD dissertation, University of Texas at Austin, Austin, TX, USA.

655

Wagner III, B.H. and Jackson, M.P.A. 2011. Viscous flow during salt welding. Tectonophysics, 510, 309-326.

Warren, J.K., 2016, Evaporites: A Compendium. Springer, Berlin, pp.1854.

660

Willis, J.J., Lock, B.E., Cornell, K.C. and Rudberg, D.A. 2001. An exposed evaporite weld and related deformational structures, Edwards Plateau, I-10 corridor, Kerrville Junction-Sonara 
667 Fig. 1. Schematic cross section (not to scale) illustrating the three main types of salt weld that can develop in salt-tectonic basins. This classification is based on the structural level at which salt evacuation occurs (i.e. deep, intermediate, and shallow), the attitude of the weld (i.e. subhorizontal or sub-vertical), and the origin of the weld (i.e. thinning of autochthonous or allochthonous salt, or squeezing and closure of a diapir) (modified from Jackson et al., 2014; see also Jackson and Cramez, 1989). The pie-charts schematically illustrate the inferred proportion of three main evaporite-related rock types that may be encountered in a primary, secondary, and tertiary welds. Note the upwards increase in halite and relative enrichment in other rock types due to "differential purification by movement" (sensu Kupfer, 1968). See text, and Jackson et al. (2014 and 2018) for full discussion.

Fig. 2. (a) Schematic cross section showing a minibasin translating along the top of an extruding salt sheet (Time 1). As the minibasin translates, its base impinges on a subsalt ramp, forming a fault weld (Time 2). This natural geometry minimizes the limitations of boundary drag and promotes nearly complete welding by viscous flow alone (modified from Wagner and Jackson, 2011). (b) Schematic diagram highlighting the formation of a complete fault weld, which forms if shear displacement occurs before, during or after salt evacuation. Concepts and terminology after Jackson and Cramez (1989), Hossack and McGuinness (1990), and Rowan et al. (1999), Wagner and Jackson (2011). Modified from Wagner and Jackson (2011).

Fig. 3. Seafloor bathymetry map of the northern Gulf of Mexico and the Sigsbee canopy. The study area is located on the mid-to-lower slope. Bathymetry map sourced from the Bureau of Ocean Energy Management (https://marinecadastre.gov/nationalviewer). Black lines show offshore protraction areas. Inset shows broader geographical location of bathymetry data.

692 Fig. 4. Maps illustrating the salt-tectonic structure of the study area. (a) base-salt seismic 693 horizon depth-map; (b) base-salt seismic horizon depth-map; (c) salt isopach (thickness) map; and (d) interpretative sketch map showing the spatial relationship of the key salt-tectonic structures identified in (a), (b), and (c). The locations of the seismic profiles in Fig. 5 are shown. Note the thrust and related secondary weld in the NE of the study area are at a shallower structural level than those found elsewhere; see Fig. 5c and d.

Fig. 5. Interpreted seismic reflection profiles showing the salt-tectonic structure of the study area, and the structural context and seismic expression of the studied salt weld and its encasing 
strata. The locations of the profiles are shown in Fig. 4, and the geological ages of the sub- and suprasalt seismic-stratigraphic units (SUs) are shown in Fig. 6. Uninterpreted seismic reflection profiles are available in Supplementary Material.

Fig. 6. Simplified stratigraphic column showing key well-log information and the petrophysical expression of the main, biostratigraphically age-constrained seismicstratigraphic units (SUs) penetrated in the borehole. The location of Fig. 8 is shown. Circled numbers on the left of the column show the borehole diameter.

Fig. 7. Isochron (thickness) maps showing temporal changes in minibasin depocentre location because of canopy advance, salt welding, and minibasin shortening and tilting. (a) SU1 Serravallian-Messinian;

(b) SU2 - Messinian;

(c) SU3 - Messinian-Piacenzian;

(d) SU4 Gelasian-Pleistocene; (e) SU5 - Late Pleistocene-Holocene(?); and (f) SU6 - Late PleistoceneHolocene(?). The position of the base-salt ramp (e.g., Fig. 5a; see also text for description and interpretation) is indicated in (a)-(c). The key intra-minibasin, sub-basin-bounding structures inferred to be active during the deposition of the Serravallian-Messinian (SU1), Messinian (SU2), and Messinian-Piacenzian (SU3) are shown; the approximate positions of these structures are inferred from their present locations as shown in Fig. 4d. Key for structures is shown in Fig. 4d. (A-H) in (a) are sub-basins described in the text and shown in Figs 4d and 5.

Fig. 8. Details of the well-log data from the depth interval c. $20170-20350 \mathrm{ft}$ in the borehole, illustrating the petrophysical expression and composition of the apparent salt weld and flanking strata (see also Fig. 9). The location of the borehole is shown in Figs 4, 5 and 7. The colourcode refers to colours shown in Fig. 6 . Note that the density and neutron porosity log responses are slightly offset from the base salt due to the 13 7/8-inch casing point being set just below the weld.

Fig. 9. Density (RHOB)-sonic slowness (DT) (i.e., velocity) cross-plot of petrophysical data from the depth interval shown in Fig. 8. Note the distinct expression of intra-weld halite, which is characterised by significantly higher density (typically $>2.4 \mathrm{~g} / \mathrm{cm}^{3}$ ) and slow sonic slowness values (typically $<80 \mathrm{us} / \mathrm{ft}$ ) (i.e., higher velocities) than underlying or overlying clastics. The range of ideal values for clean halite are shown (taken from Rider and Kennedy, 2011), as are those documented by Jackson et al. (2018) from the northern Gulf of Mexico. See text for discussion. 
736 Fig. 10. Schematic diagram showing the general, simplified salt-tectonic evolution of the 737 studied minibasin, salt weld, and associated structures. The stages in the diagram are very 738 broadly tied to the six key stages described in the text: (a) and (b) Stage 1 (Serravallian739 Messinian) - minibasin nucleation and translation; (c) Stage 2 (Messinian) - minibasin 740 translation, welding, collision, and contraction, and depocentre coalescence; (d) Stages 3 741 (Messinian-Piacenzian) and 4 (Gelasian-Pleistocene) - contraction, diapir inflation, and 742 minibasin tilting; (e) Stage 5 and 6 (Late Pleistocene-Holocene?) - minibasin translation, 743 collision, contraction, and decay. Minibasin A-C do not correspond to those described in the 744 text; they are simply labelled here in so that their relative positions can be tracked during Stages 745 1-3. Note also that sheet/canopy inflation is inferred to result from the squeezing of diapiric 746 feeders (Peel et al., 1995), which may lie outside of the displayed profile, and that intra747 minibasin accommodation (in Stages 4 and 5) was principally generated by the passive rise of 748 flanking diapirs rather than the subsidence of the minibasins. 
Fig. 1
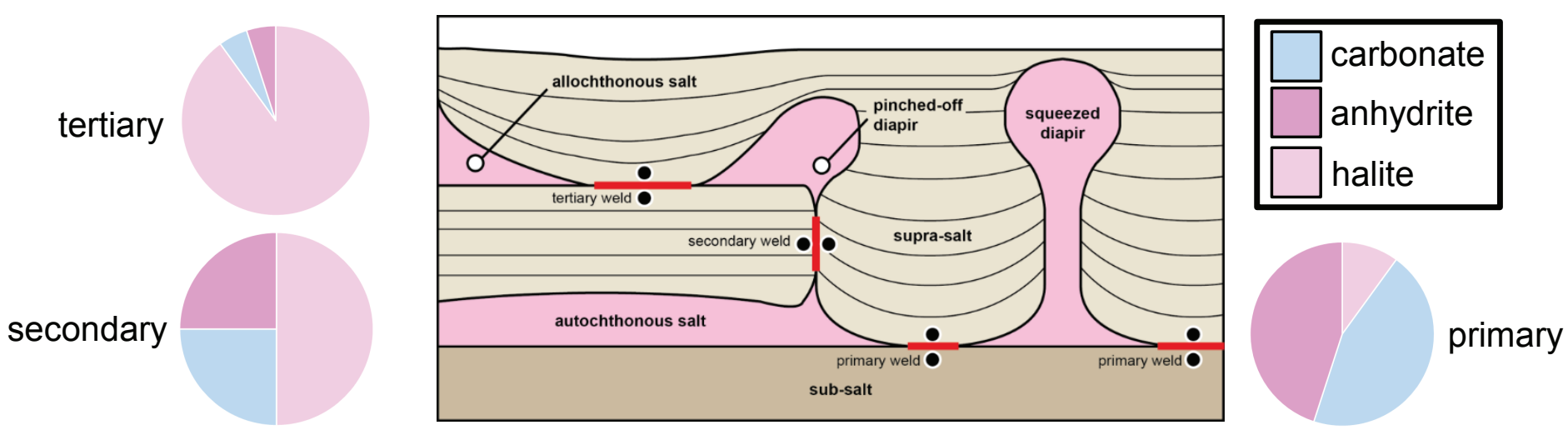

Fig. 1. Schematic cross section (not to scale) illustrating the three main types of salt weld that can develop in salt-tectonic basins. This classification is based on the structural level at which salt evacuation occurs (i.e. deep, intermediate, and shallow), the attitude of the weld (i.e. sub-horizontal or sub-vertical), and the origin of the weld (i.e. thinning of autochthonous or allochthonous salt, or squeezing and closure of a diapir) (modified from Jackson et al., 2014; see also Jackson and Cramez, 1989). The pie-charts schematically illustrate the inferred proportion of three main evaporite-related rock types that may be encountered in a primary, secondary, and tertiary welds. Note the upwards increase in halite and relative enrichment in other rock types due to "differential purification by movement" (sensu Kupfer, 1968). See text, and Jackson et al. (2014 and 2018) for full discussion. 
Fig. 2

translating and subsiding minibasin

(a)

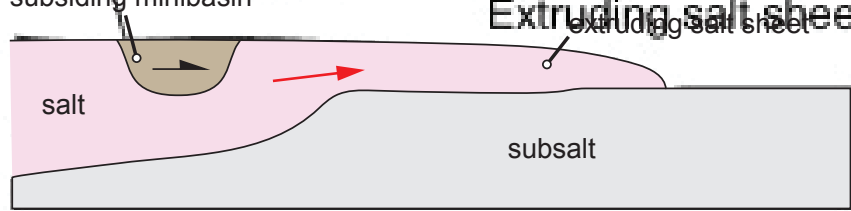

(b)
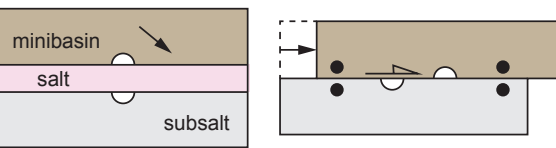

shear displacement

direction of salt sheet advance

relative motion of minibasin to subsalt

welded (obstructed)

minibasin

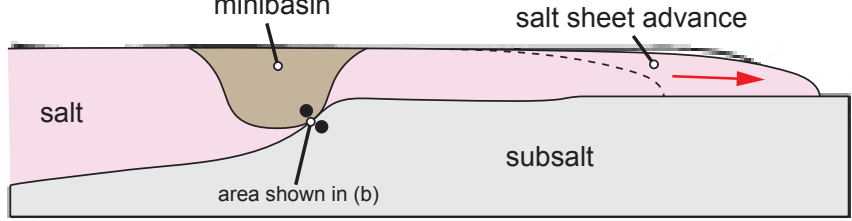

$5 \mathbf{~ k m}$

Fig. 2. (a) Schematic cross section showing a minibasin translating along the top of an extruding salt sheet (Time 1). As the minibasin translates, its base impinges on a subsalt ramp, forming a fault weld (Time 2). This natural geometry minimizes the limitations of boundary drag and promotes nearly complete welding by viscous flow alone (modified from Wagner and Jackson, 2011). (b) Schematic diagram highlighting the formation of a complete fault weld, which forms if shear displacement occurs before, during or after salt evacuation. Concepts and terminology after Jackson and Cramez (1989), Hossack and McGuinness (1990), and Rowan et al. (1999), Wagner and Jackson (2011). Modified from Wagner and Jackson (2011). 
Fig. 3

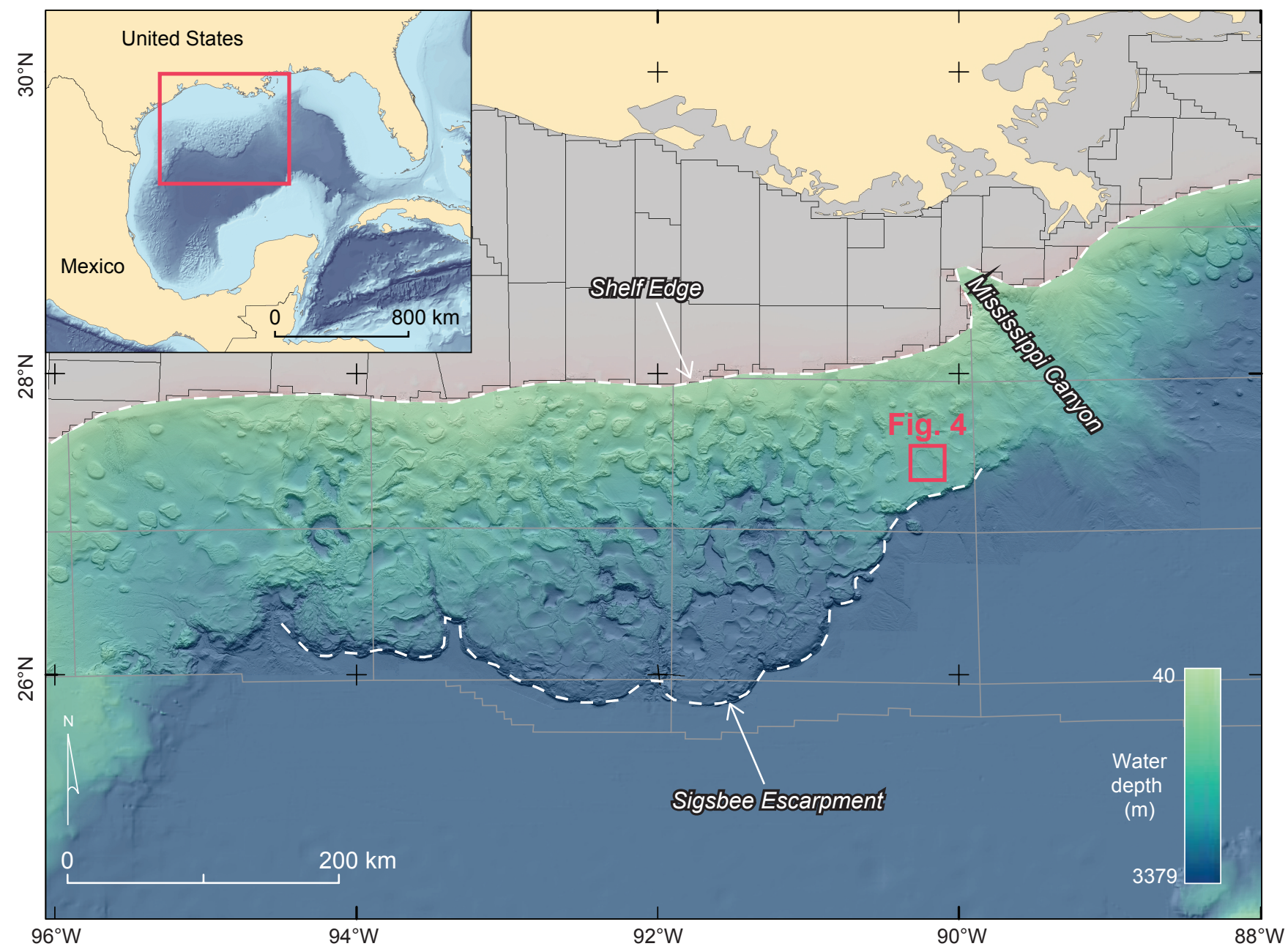

Fig. 3. Seafloor bathymetry map of the northern Gulf of Mexico and the Sigsbee canopy. The study area is located on the mid-to-lower slope. Bathymetry map sourced from the Bureau of Ocean Energy Management (https://marinecadastre.gov/nationalviewer). Black lines show offshore protraction areas. Inset shows broader geographical location of bathymetry data. 
Fig. 4
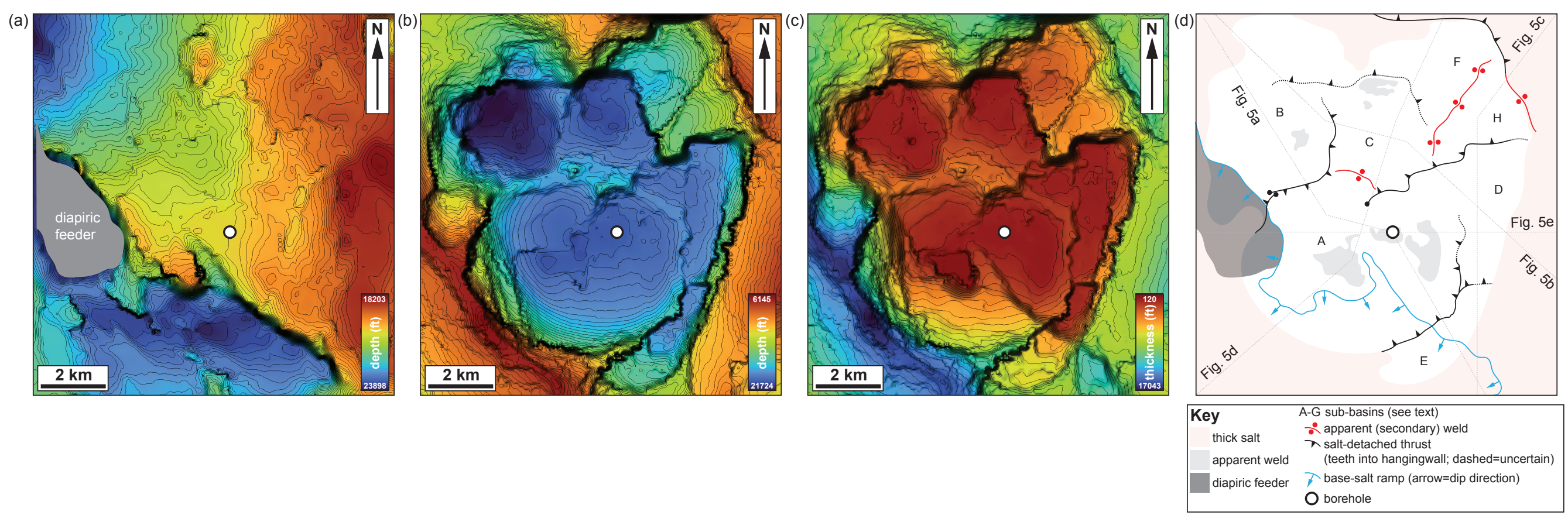

Fig. 4. Maps illustrating the salt-tectonic structure of the study area. (a) base-salt seismic horizon depth-map; (b) base-salt seismic horizon depth-map; (c) salt isopach (thickness) map; and (d) interpretative sketch map showing the spatial relationship of the key salt-tectonic structures identified in (a), (b), and (c). The locations of the seismic profiles in Fig. 5 are shown. Note the thrust and related secondary weld in the NE of the study area are at a shallower structural level than those found elsewhere; see Fig. $5 \mathrm{c}$ and d. 
Fig. 5
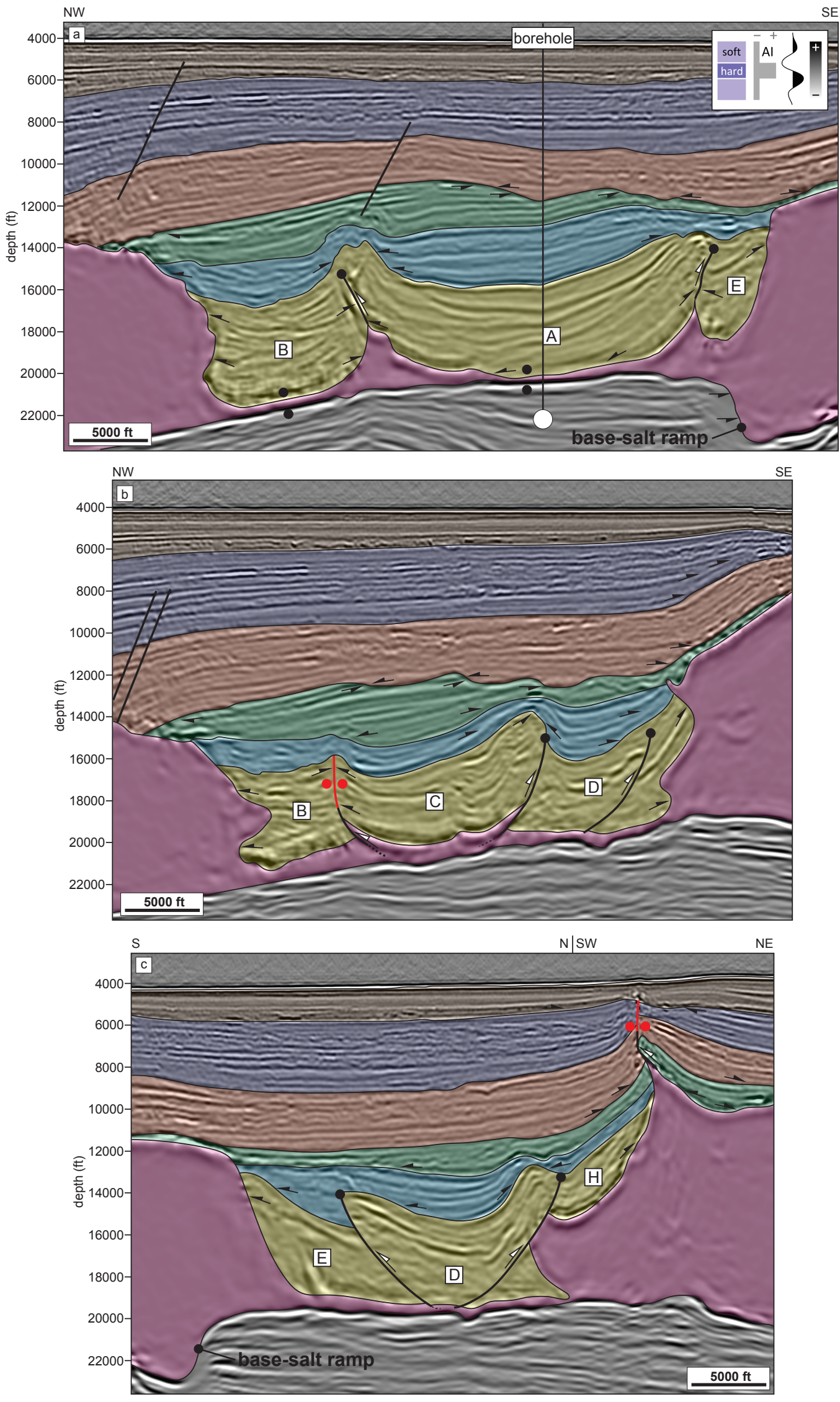
Fig. 5
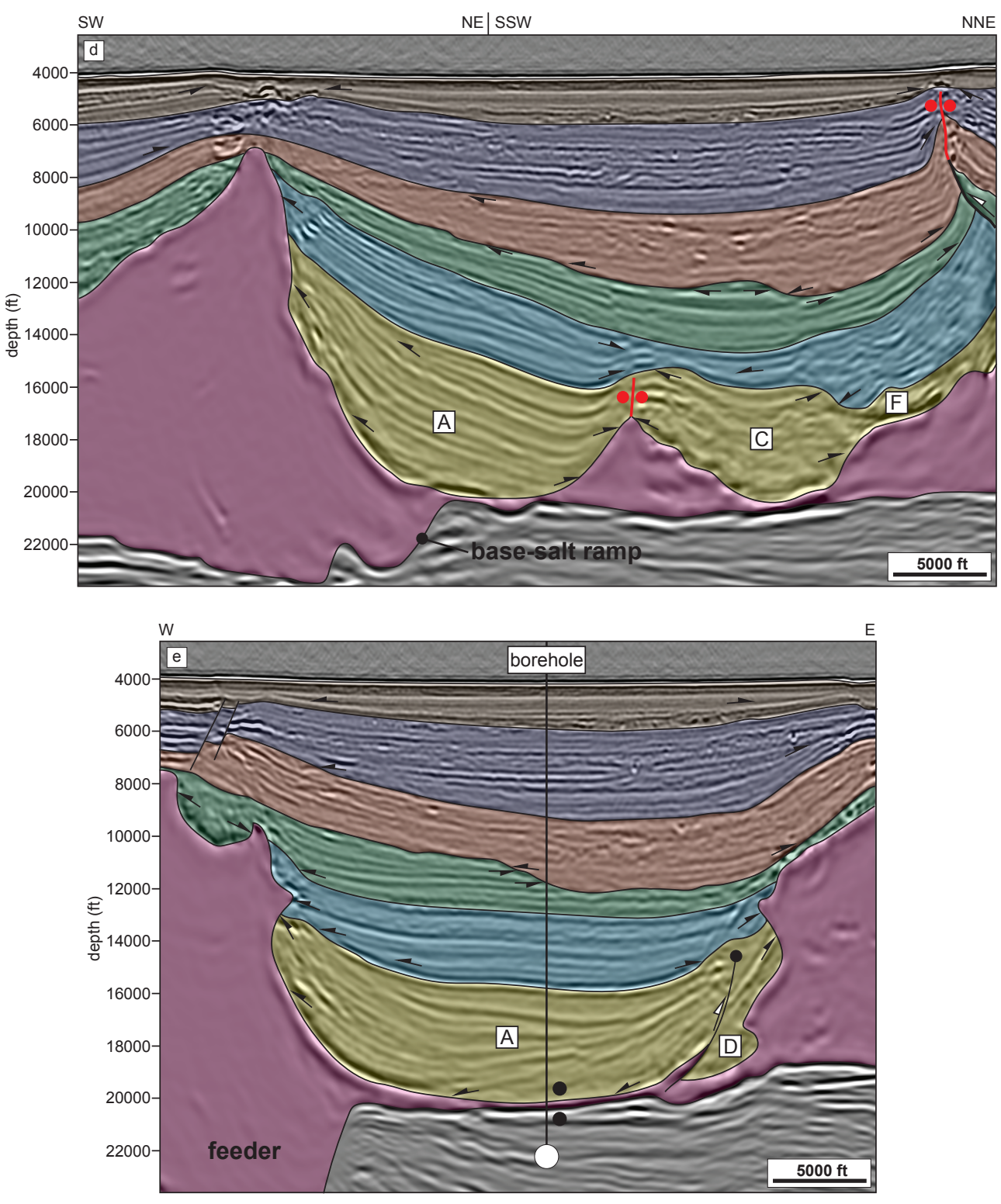

\begin{tabular}{|cl|}
\hline Key & A-G sub-basins (see Fig. 4d) \\
SU5 & onlap \\
SU4 & - erosional truncation \\
SU4 & - (apparant) downlap \\
SU3 & $/$ reverse fault \\
SU2 & $\bullet$ normal fault \\
SU1 & $:$ (apparant) secondary weld \\
(allochthonous) salt
\end{tabular}

Fig. 5. Interpreted seismic reflection profiles showing the salt-tectonic structure of the study area, and the structural context and seismic expression of the studied salt weld and its encasing strata. The locations of the profiles are shown in Fig. 4, and the geological ages of the suband suprasalt seismic-stratigraphic units (SUs) are shown in Fig. 6. Uninterpreted seismic reflection profiles are available in Supplementary Material. 
Fig. 6

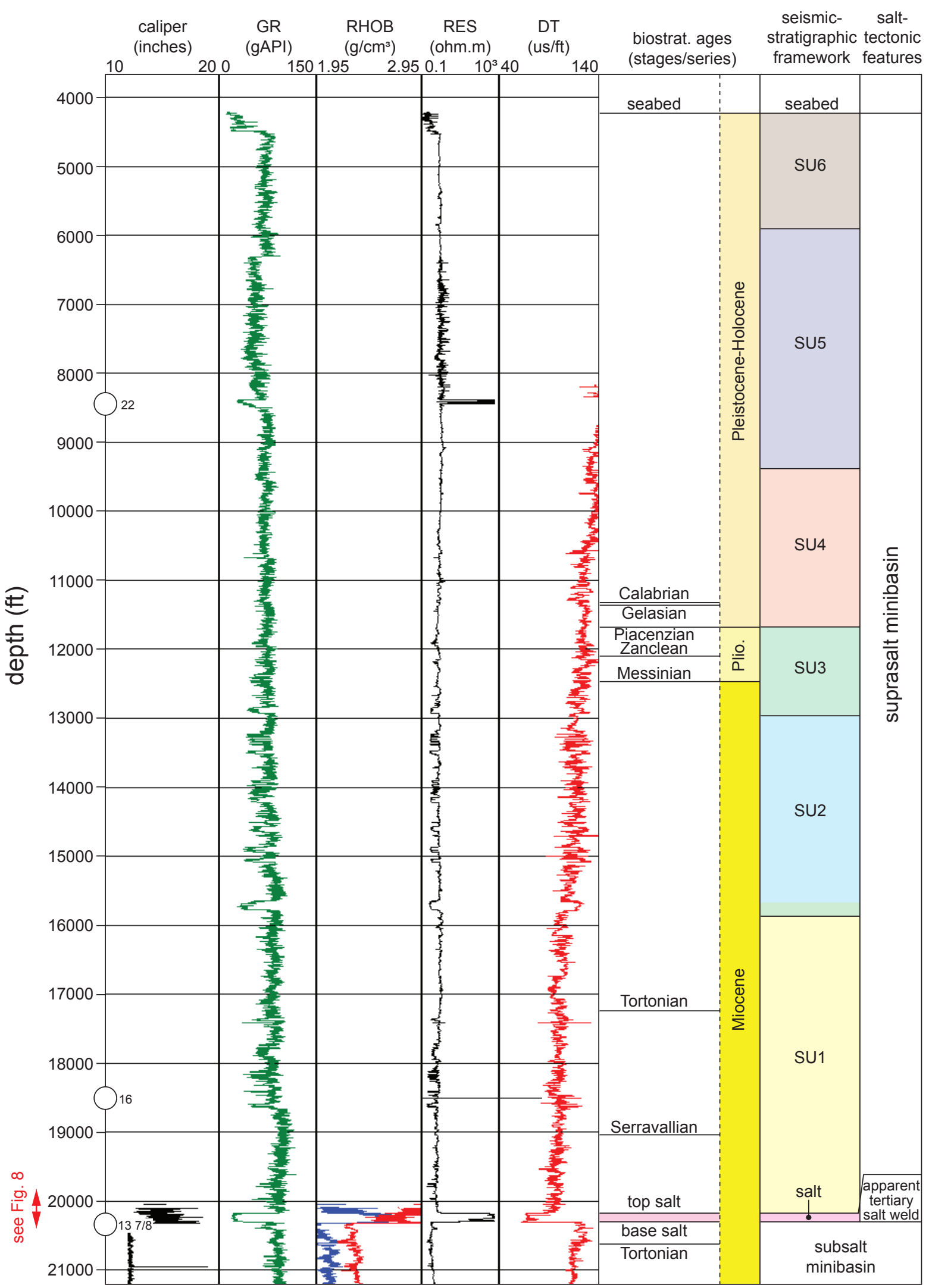

Fig. 6. Simplified stratigraphic column showing key well-log information and the petrophysical expression of the main, biostratigraphically age-constrained seismic-stratigraphic units (SUs) penetrated in the borehole. The location of Fig. 8 is shown. Circled numbers on the left of the column show the borehole diameter. 
Fig. 7
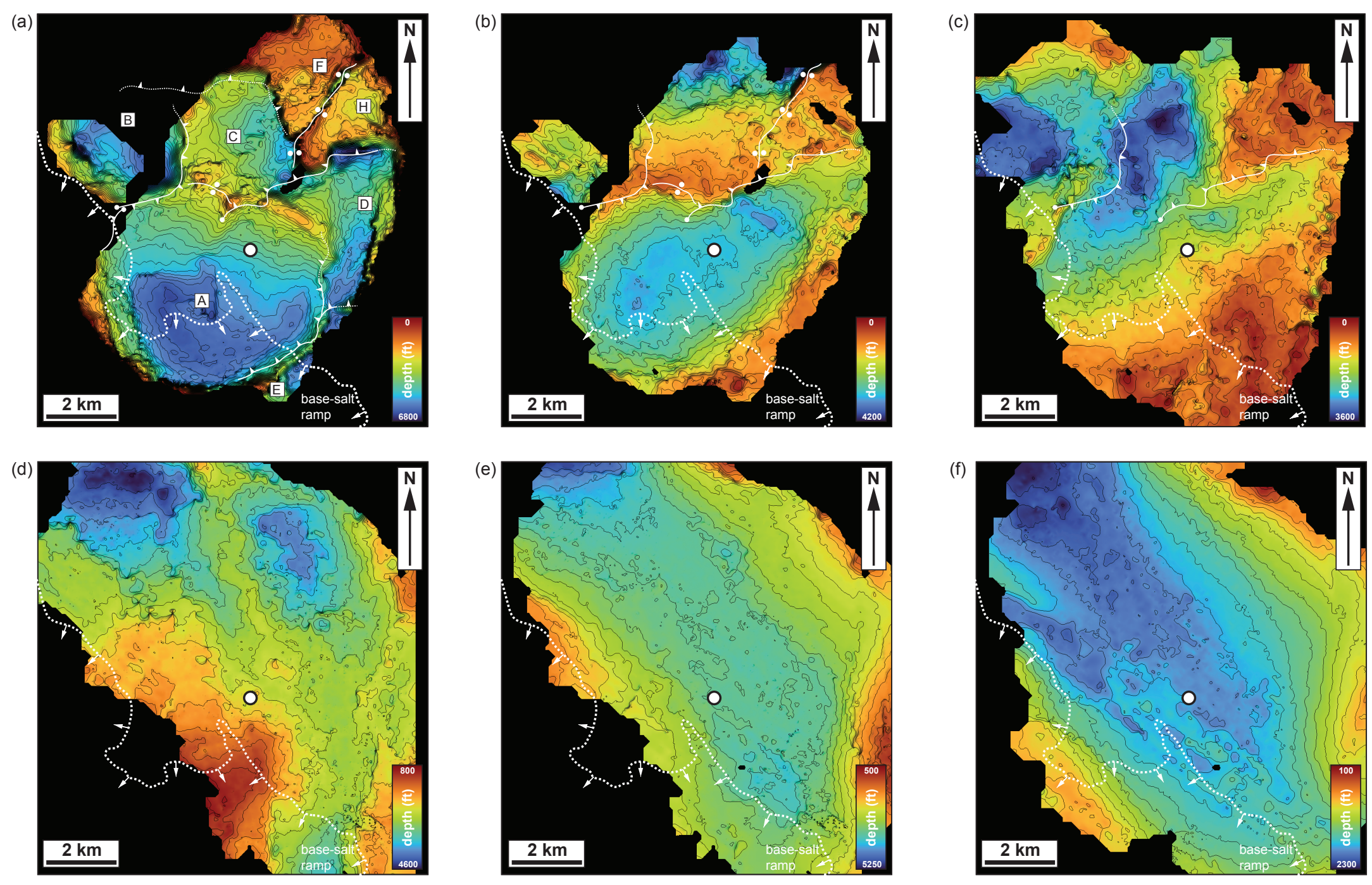

Fig. 7. Isochron (thickness) maps showing temporal changes in minibasin depocentre location because of canopy advance, salt welding, and minibasin shortening and tilting. (a) SU1 - Serravallian-Messinian; (b) SU2 - Messinian; (c) SU3 - Messinian-Piacenzian; (d) SU4 - Gelasian-Pleistocene; (e) SU5 - Late Pleistocene-Holocene(?); and (f) SU6 - Late Pleistocene-Holocene(?). The position of the base-salt ramp (e.g., Fig. 5a; see also text for description and interpretation) is indicated in (a)-(c). The key intra-minibasin, sub-basin-bounding structures inferred to be active during the deposition of the Serravallian-Messinian (SU1), Messinian (SU2), and Messinian-Piacenzian (SU3) are shown; the approximate positions of these structures are inferred from their present locations as shown in Fig. 4d. Key for structures is shown in Fig. 4d. (A-H) in (a) are sub-basins described in the text and shown in Figs 4d and 5. 
Fig. 8

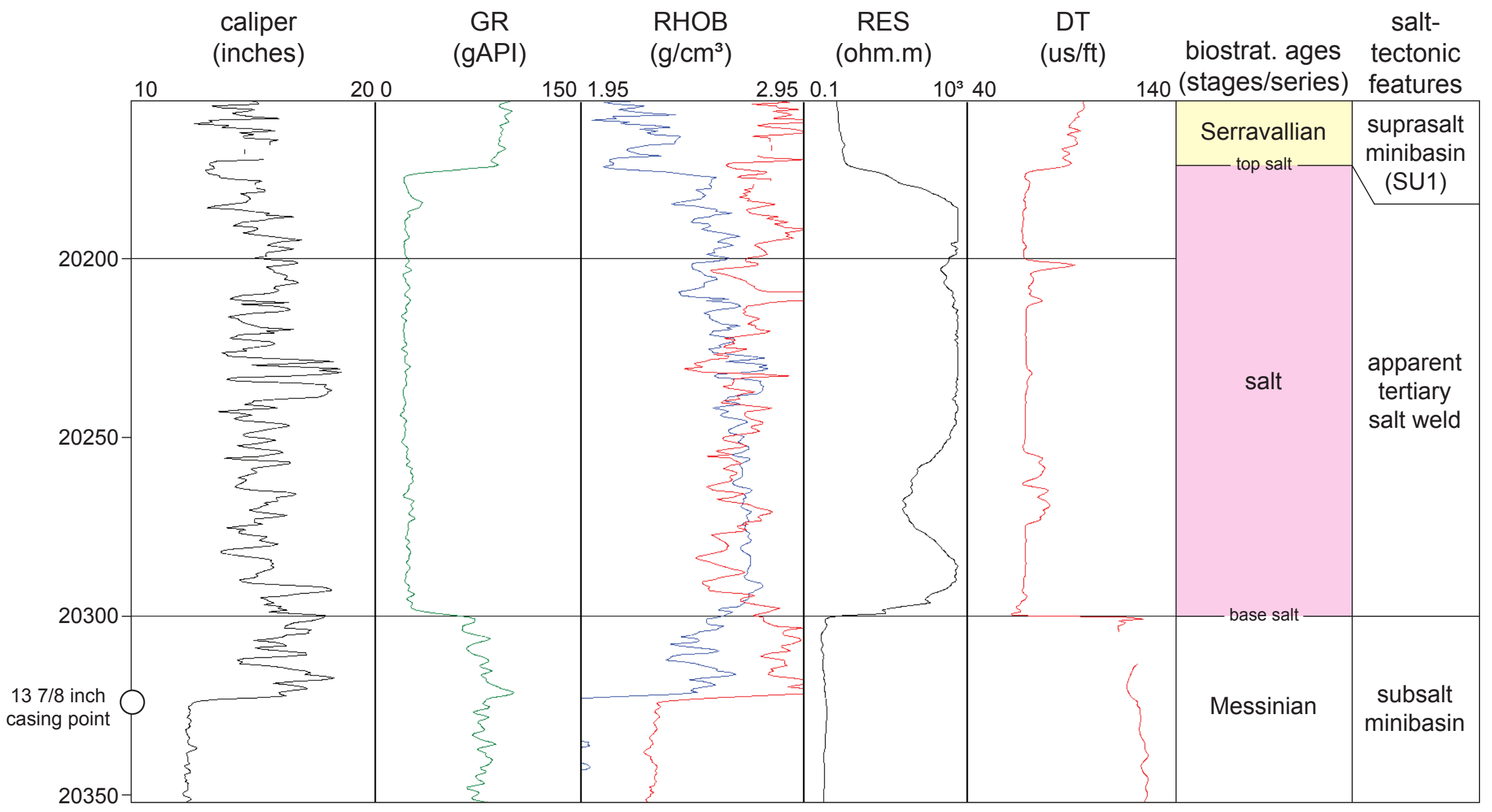

Fig. 8. Details of the well-log data from the depth interval c. $20170-20350 \mathrm{ft}$ in the borehole, illustrating the petrophysical expression and composition of the apparent salt weld and flanking strata (see also Fig. 9). The location of the borehole is shown in Figs 4, 5 and 7. The colour-code refers to colours shown in Fig. 6 . Note that the density and neutron porosity log responses are slightly offset from the base salt due to the $137 / 8$-inch casing point being set just below the weld. 
Fig. 9

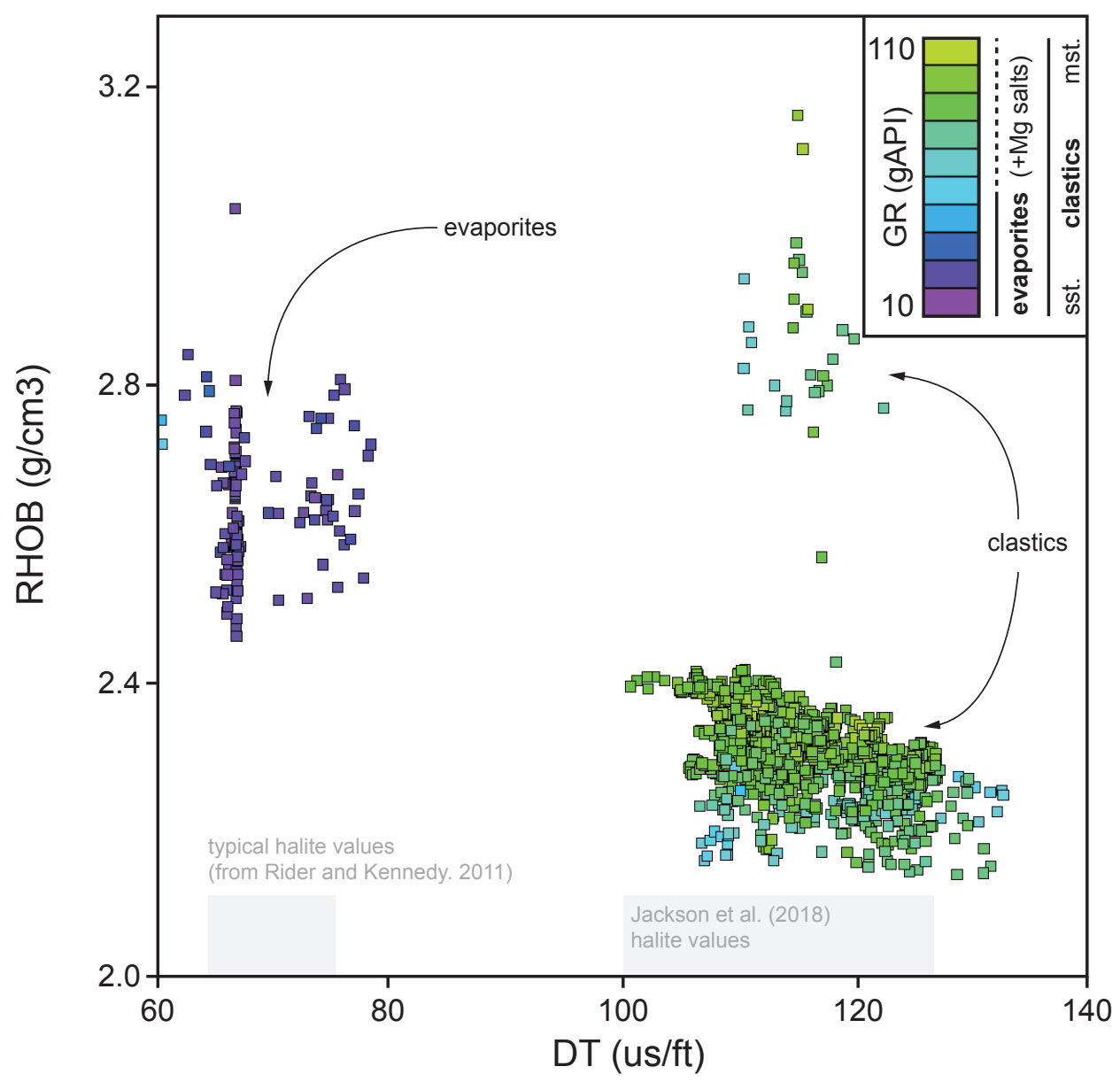

Fig. 9. Density (RHOB)-sonic slowness (DT) (i.e., velocity) cross-plot of petrophysical data from the depth interval shown in Fig. 8. Note the distinct expression of intra-weld halite, which is characterised by significantly higher density (typically $>2.4 \mathrm{~g} / \mathrm{cm} 3$ ) and slow sonic slowness values (typically $<80$ us/ft) (i.e., higher velocities) than underlying or overlying clastics. The range of ideal values for clean halite are shown (taken from Rider and Kennedy, 2011), as are those documented by Jackson et al. (2018) from the northern Gulf of Mexico. See text for discussion. 
Fig. 10

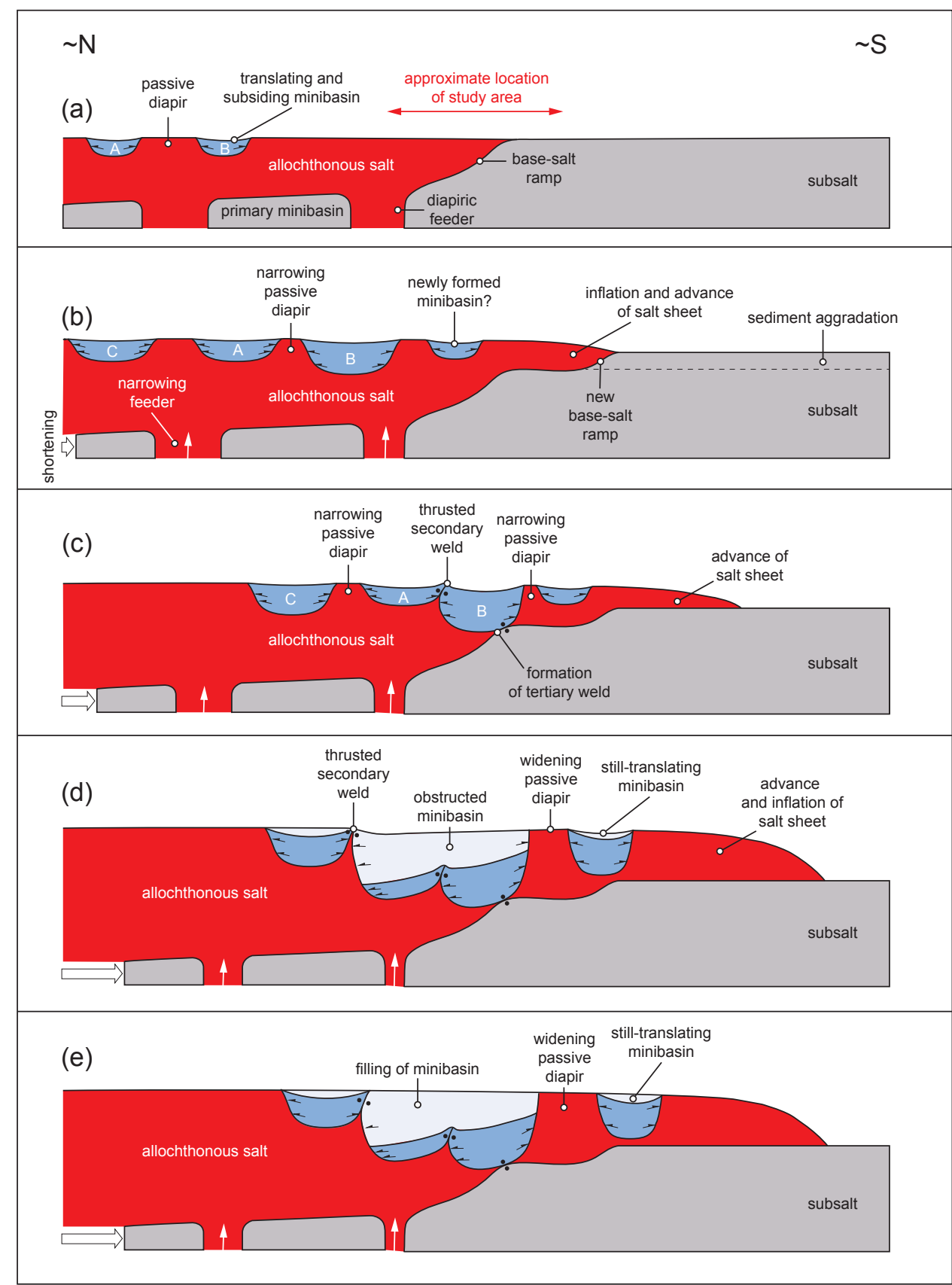

Fig. 10. Schematic diagram showing the general, simplified salt-tectonic evolution of the studied minibasin, salt weld, and associated structures. The stages in the diagram are very broadly tied to the six key stages described in the text: (a) and (b) Stage 1 (Serravallian-Messinian) - minibasin nucleation and translation; (c) Stage 2 (Messinian) - minibasin translation, welding, collision, and contraction, and depocentre coalescence; (d) Stages 3 (Messinian-Piacenzian) and 4 (Gelasian-Pleistocene) - contraction, diapir inflation, and minibasin tilting; (e) Stage 5 and 6 (Late Pleistocene-Holocene?) - minibasin translation, collision, contraction, and decay. Minibasin A-C do not correspond to those described in the text; they are simply labelled here in so that their relative positions can be tracked during Stages 1-3. Note also that sheet/canopy inflation is inferred to result from the squeezing of diapiric feeders (Peel et al., 1995), which may lie outside of the displayed profile, and that intra-minibasin accommodation (in Stages 4 and 5) was principally generated by the passive rise of flanking diapirs rather than the subsidence of the minibasins. 